\title{
The Mormon Explanation of Near-Death Experiences
}

\author{
Craig R. Lundahl \\ Western New Mexico University \\ Harold A. Widdison \\ Northern Arizona University
}

\begin{abstract}
This paper describes an explanation of the near-death experience (NDE) based on the writings of Mormon leaders. The Mormon explanation states that NDEs are brief glimpses into a second world that exists parallel to the world in which we exist. This tangible sphere, called the spirit world, is a place where all those who have died live. The transition from this world to the next is a pleasant experience. At death, the spirit or life force called the spiritual body leaves the physical body, retaining the unique individual personality but without the limitations of the physical body. The spiritual body has a form resembling the physical body and also substance, though of a different nature than that of the biological body. While out of the physical body, the individual may meet others, usually close relatives, who have come to escort the person or to inform the person that he or she must return to the body. During the near-death experience, the individual passes through natural death but is recalled to inhabit the physical body again.
\end{abstract}

\section{INTRODUCTION}

About twenty years ago, a modern resurgence of interest in deathrelated phenomena began with the investigation of Karlis Osis (1961) on the visions of dying patients as reported by physicians and nurses. About ten years later the study of near-death had its origins in the work of psychiatrist Russell Noyes and his co-workers (Noyes, 1972; Noyes and Kletti, 1972; Noyes and Kletti, 1976a; Noyes and Kletti, 1976b; Noyes, 1977; Noyes, Hoenk, Kuperman, and Slymen, 1977; Noyes and Slymen, 1978-1979; Noyes, 1979; Noyes, 1980); three years later the near-death experience (NDE) was identified and delineated by psychiatrist Raymond Moody. Primarily as a result of Moody's well-known study of 150 cases of people who experienced apparent clinical death or a near-fatal encounter with death and the study's subsequent publication in the popular book, Life After Life (1975), research interest in the near-death experience has increased. 


\section{EXPLANATIONS OF NEAR-DEATH EXPERIENCES}

Many medical and behavioral scientists have come forward with explanations for the near-death experience. They include such factors as drugs and sensory deprivation (Palmer, 1978; Siegel, 1980), cerebral anoxia and temporal lobe seizures (McHarg, 1978), religious expectations (Palmer, 1978), prior social conditioning (Rodin, 1980), the depersonalization syndrome (Noyes and Kletti, 1976a), the denial of death (Ehrenwald, 1978), and the replay of the birth experience (Sagan, 1979).

Researchers who have attempted to evaluate these explanations agree, in general, that they are grossly inadequate. These explanations either fit only a minute proportion of the reported near-death experiences or else describe experiences other than true NDEs (Moody, 1975; Osis and Haraldsson, 1977; Sabom and Kreutziger, 1978; Ring, 1980; Grosso, 1981; Sabom, 1982). (For detailed critiques of these theories, see Ring (1980), Grosso (1981), and Sabom (1982).)

More recently advanced explanations for near-death phenomena seem to have developed out of the survival hypothesis promulgated primarily by Osis and Haraldsson (1977), which suggests that an element of human personality survives after death, or out of neardeath research itself. These recent explanations of the near-death experience include a postulation by Motoyama of the existence of three interpenetrating bodies called the physical, astral, and causal bodies. According to this postulation, all these bodies are connected to one another by the chakras (energy vortices posited by yoga), and as higher chakras are developed, direct experiential access to the attributes of the non-physical bodies takes place (Ring, 1981).

Ring (1980) suggested that the near-death experience is an outof-body experience involving a gradual shift of consciousness from the ordinary world of appearance (this world) to a holographic reality of frequency domains where there is no time and space but an expanded awareness of all occurrences, and where one may meet a being of light, or one's total self, and be reunited with it.

In another recently offered explanation for the near-death experience, Grosso's (1981) Archetype of Death suggests that a person's mind merges with the unconscious mind of mankind at death but at the same time is able to survive as a unique personality. These recent explanations of near-death phenomena have not been given much scrutiny.

The objective of this article is to present a new theoretical expla- 
nation for the near-death experience, based on the writings, beginning a hundred and forty years ago, of leaders of The Church of Jesus Christ of Latter-day Saints, a religious group more commonly known as the Mormons. We will present specifically those aspects of Mormon doctrine that relate to the common elements mentioned in typical near-death experiences, including (1) the nature of the non-physical body, (2) the nature of the out-of-body experience, including the transition from life to death, the spirit world, and the occupants of the spirit world, and (3) the return to the body.

\section{THE MORMON EXPLANATION OF NEAR-DEATH EXPERIENCES}

\section{The Nature of the Non-Physical Body}

Most near-death experiencers report surprise when they discover themselves outside of their physical bodies looking down on them much as if they were spectators at a play. To most individuals, consciousness and the five senses are biological properties, so being out of the body, observing the actions of those around the body, hearing themselves pronounced dead, etc., is surprising. It would appear from these reports that the individual is comprised of two basic elements, the biological mass made of the physical body and a second component that can continue to sense, experience, and maintain its identity away from the physical body.

In the writings of an early Mormon Church leader, a person is described as having two bodies, a physical body and a spirit body:

[Man is a] dual being, composed of the spirit which gives life, force, intelligence and capacity to man, and the body which is the tenement of the spirit and is suited to its form, adapted to its necessities, and acts in harmony with and to its utmost capacity yields obedience to the will of the spirit. The body is dependent upon the spirit, and the spirit during its natural occupancy of the body is subject to the laws which apply to and govern it in the mortal state (Joumal of Discourses, 1966, Vol. 23, p. 169).

Of these two bodies, the spirit body is the life force and intelligence and is capable of dwelling within the physical body. The physical body acts as a covering and a protection for the spirit body (Journal of Discourses, Vol. 19).

The spirit body that occupies the physical body has a form and likeness similar to the physical body except that any deformities that exist in the physical body do not exist in the spirit body (Journal 
of Discourses, Vol. 15). As one Mormon leader put it when asked what his spirit looked like when it was disembodied: "Why, just look at me now, and you can answer the question .... Whether inside or out of [the physical body], we are the same beings .... The same features exactly" (Journal of Discourses, Vol. 19, p. 273).

The physical body is composed of matter, and so is the spirit body. However, the spirit body is composed of matter so refined as not to be tangible to this coarser organization on earth (Widtsoe, 1954; Doctrine and Covenants, 1979).

When the spirit body separates from the physical body, it still retains the senses of sight, hearing, feeling, tasting, and smelling, and the ability to converse (Journal of Discourses, Vol. 19). Other qualities of the spirit body include freedom from illness or disability (Heinerman, 1978), increased mental capabilities such as quickened memory and the ability to consider many different ideas at the same time (Heinerman, 1978; Crowther, 1967), movement with the speed of lightning (Widtsoe, 1954), the ability to communicate in a variety of ways (Widtsoe, 1954), and the use of other powers and senses not available to mortal beings such as greater powers of vision (Crowther, 1967).

\section{The Out-of-Body Experience}

The transition from life to death. Mormon doctrine teaches that the life force of the body, i.e., the spirit, existed prior to the birth of the individual. The spirit has a unique personality that has developed prior to birth (Pearl of Great Price, 1979). At death the spirit body that entered the physical body at birth leaves the physical body and immediately finds itself in a spirit world (Widtsoe, 1954; McConkie, 1966). This transition from death into a spirit world will be, according to one Mormon Church leader, a pleasant one:

We shall turn around and look upon it [the valley of death] and think when we have crossed it, why this is the greatest advantage of my whole existence, for I have passed from a state of sorrow, grief, mourning, woe, misery, pain, anguish and disappointment into a state of existence where I can enjoy life to the fullest extent as far as that can be done without a body (Heinerman, 1978, p. 26).

Thus, "death is merely a change from one status or sphere of existence to another" (McConkie, 1966, p. 184). Furthermore, "life and work and activity all continue in the spirit world. Men have the same talents and intelligence there which they had in this life. 
They possess the same attitudes, inclinations, and feelings there which they had in this life" (McConkie, 1966, p. 762). In other words,

[a person goes] from this condition of existence into the other sphere with the same feelings, to some extent at least, as we have here. If we have had knowledge, we shall have it there. There will be just as much distinction between spirits there as you find between spirits here . . . We will have to work there to grow and to make progress just as we have here, though the facilities will be better there than they are here (Heinerman, 1978, p. 19).

The spirit world. As stated previously, Mormons believe that when an individual dies, his life force (spirit) goes to a place of residence a spirit world. The spirit world is a tangible sphere where disembodied spirits live. To the Mormons,

[this spirit world] is here on the very planet where we are born; or in other words, the earth and other planets of like sphere have their inward or spiritual spheres, as well as their outward, or temporal. The one is peopled by temporal tabernacles, and the other by spirits. A veil is drawn between the one sphere and the other, whereby all the objects in the spiritual sphere are rendered invisible to those in the temporal (Pratt, 1891, pp. 132-133).

It is a world that is difficult to describe, as attested to by many NDErs and as illustrated in this quotation from a Mormon leader: "The brightness and glory of the next apartment is inexpressible" (Widtsoe, 1954, p. 380). Nevertheless, everything in the spirit world will appear as natural as things do in the physical world. "There as here, all things will be natural, and you will understand them as you now understand natural things" (Widtsoe, 1954, p. 380).1

The world of spirits is so glorious in comparison to ours that no words exist in any language to describe it. Only under unique conditions such as an NDE are mortal beings able to glimpse it. Yet while the individual is going through an NDE, it seems entirely natural and appropriate.

Occupants of the spirit world. According to Mormon doctrine, the world of spirits is the residence for all those who have died (Smith, 1974). Immediately upon death, the spirits of all men and women go to the spirit world. It is a tangible sphere where disembodied spirits live in one of several conditions according to what their mortal lives have merited (Mouritsen, 1977).

Mormons also teach that the family is an eternal unit. Marriage 
is not intended to last only until interrupted by the death of one spouse but is to last beyond the grave (Doctrine and Covenants, 1979). Family members, be they living or deceased, are concerned about each other. Those who have died are aware when a close family member or even a friend is dying. A Mormon leader once noted,

We have more friends behind the veil than on this side, and they will hail us more joyfully than you were ever welcomed by your parents and friends in this world, and you will rejoice more when you meet them than you ever rejoiced to see a friend in this life Uoumal of Discourses, Vol. 6 , P. 349).

Heber C. Kimball, an early Mormon Church leader, recorded the following report of an experience of his friend, Jedediah M. Grant, just before Grant died:

He said to me, Brother Heber, I have been into the spirit world two nights in succession, and of all the dreads that ever came across me, the worst was to have to return to my body, though I had to do it.

Kimball went on to describe Grant's encounter with his deceased wife and daughter:

He saw his wife, she was the first person that came to him. He saw many that he knew, but did not have conversation with any but his wife Caroline. She came to him and he said that she looked beautiful and had their little child, that died on the plains, in her arms, and said "Mr. Grant, here is little Margaret; you know that the wolves ate her up; but it did not hurt her, here she is all right" (Journal of Discourses, Vol. 14, pp. 135-136).

An early Mormon publication recorded the following advice to a mother who had buried three of her children:

When the second one joined the first behind the veil, what occurred? The new arrival told of matters in the earthly home she had just left. When the third joined the other two, what happened? The same thing. When our loved ones in this world pass into the next they convey news of us to our loved ones there (Bennion, 1909, pp. 1226-1231).

The Return to the Body

Many NDErs report that the major reason they came back to their bodies is that they had unfinished tasks or that specific personal needs had not yet been met (Moody, 1975; Osis and Haraldsson, 1977). This agrees with the observation of a Mormon Church leader 
that "some spirits who have experienced death are called back to inhabit their physical bodies again. These persons pass through the natural or temporal death twice" (McConkie, 1966, pp. 185-186).

\section{CONCLUSION}

In reviewing the writings and beliefs of the Mormons, the authors were struck with how closely these writings parallel the typical near-death experience. This paper was written to show how this aspect of Mormon doctrine could be used to provide a theoretical framework for the NDE phenomenon.

In summary, the Mormon explanation of the NDE supports the reports of NDEs, not as hallucinations or delusions, but as real experiences. These experiences are held to be brief glimpses into a second world that exists parallel to the world in which we exist. This second world is similar to our world yet, at the same time, different from ours. The transition from this world to the next is pleasant and peaceful, a relief from the pain, fears, and agonies often associated with the dying process of the physical body. At death the spirit or the life force leaves the physical body, retains the senses, and is capable of reflection about what is happening. The unique personality of the individual continues but without the limitations imposed by genetic malfunctions, age, and disease. The spirit body has form in that the physical body resembles it, and has substance, though of a different nature than that of the biological body. While out of the physical body, the individual may meet others, usually persons who have come to escort him or her or to inform the individual that he or she must return to the physical body. These others are usually close relatives and are always there to assist in one way or another. At the time of death the physical body becomes a lifeless shell that eventually decomposes, whereas the spirit body goes to another sphere of existence called the spirit world. The spirit world is a separate, unperceived sphere of this earth that serves as the residence for all those who have died. During a near-death experience, the NDEr passes through natural death but is recalled to inhabit the physical body again.

The explanation summarized above, which is based on Mormon doctrine, seems to come closer to encompassing the entire neardeath experience as described by many researchers in the field of near-death studies than any other advanced so far. We invite researchers to examine NDEs using this theoretical framework. 


\section{NOTE}

1. For a more detailed description of this spirit world, see Craig R. Lundahl, "The Perceived Other World in Mormon Near-Death Experiences: A Social and Physical Description," Omega, 1981-82, $12,319-327$.

\section{REFERENCES}

Bennion, S.O. Why do little children die? Liahona the Elder's Journal, $1909,6,1226-1231$.

Book of Mormon. Salt Lake City, Utah: The Church of Jesus Christ of Latter-day Saints, 1979.

Crowther, D.S. Life Everlasting. Salt Lake City, Utah: Bookcraft, Inc., 1967.

Doctrine and Covenants. Salt Lake City, Utah: The Church of Jesus Christ of Latter-day Saints, 1979.

Ehrenwald, J. The ESP Experience. New York: Basic Books, 1978. Grosso, M. Toward an explanation of near-death phenomena. Anabiosis, 1981, 1, 3-26.

Heinerman, J. Spirit World Manifestations. Salt Lake City, Utah: Magazine Printing and Publishing, 1978.

Joumal of Discourses. 26 vols. Los Angeles: General Printing and Lithograph Company, 1966.

McConkie, B.R. Mormon Doctrine. Salt Lake City, Utah: Bookcraft, Inc., 1966.

McHarg, J.F. Review of At the Hour of Death, by K. Osis and E. Haraldsson. Journal of the Society for Psychical Research, $1978,49,885-887$.

Moody, R.A. Life After Life. Atlanta: Mockingbird Books, 1975. Mouritsen, D.C. The spirit world, our next home. The Ensign, 1977, January, 47-51.

Noyes, R. The experience of dying. Psychiatry, 1972, 35, 174-184. Noyes, R. Panoramic memory: a response to the threat of death. Omega, 1977, 8, 181-194.

Noyes, R. Near-death experiences: their interpretation and significance. In R. Kastenbaum (Ed.), Between Life and Death. New York: Springer, 1979.

Noyes, R. Attitude change following near-death experiences. Psychiatry, 1980, 43, 234-242. 
Noyes, R., Hoenk, P.R., Kuperman, S., and Slymen, D.J. Depersonalization in accident victims and psychiatric patients. Journal of Nervous and Mental Disease, 1977, 164, 403-407.

Noyes, R., and Kletti, R. The experience of dying from falls. Omega, 1972, 3, 45-52.

Noyes, R., and Kletti, R. Depersonalization in the face of life-threatening danger: a description. Psychiatry, 1976a, 39, 19-27.

Noyes, R., and Kletti, R. Depersonalization in the face of lifethreatening danger: an interpretation. Omega, 1976b, 7, 103-114.

Noyes, R., and Slymen, D.J. The subjective response to life-threatening danger. Omega, 1978-79, 9, 313-321.

Osis, K. Deathbed Observations by Physicians and Nurses. New York: Parapsychological Foundation, 1961.

Osis, K., and Haraldsson, E. At the Hour of Death. New York: Avon, 1977.

Palmer, J. Correspondence: deathbed apparitions and the survival hypothesis. Journal of the American Society for Psychical Research, 1978, 72, 392-395.

Pearl of Great Price. Salt Lake City, Utah: The Church of Jesus Christ of Latter-day Saints, 1979.

Pratt, P.P. Key to the Science of Theology. Salt Lake City, Utah: 1891.

Ring, K. Religiousness and near-death experiences: an empirical study. Paper presented at the American Psychological Association Convention, September, 1979, New York.

Ring, K. Life at Death. New York: Coward, McCann and Geoghegan, 1980.

Ring, K. Paranormal and other non-ordinary aspects of near-death experiences: implications for a new paradigm. Essence, 1981, 5, 33-51.

Rodin, E.A. The reality of death experiences: a personal perspective. Journal of Nervous and Mental Disease, 1980, 168, 259-263.

Sabom, M.B. Recollections of Death. New York: Harper and Row, 1982.

Sabom, M.B., and Kreutziger, S.A. Physicians evaluate the near-death experience. Theta, 1978, 6, 1-6.

Sagan, C. Broca's Brain. New York: Random House, 1979.

Siegel, R.K. The psychology of life after death. American Psychologist, 1980, 35, 911-931.

Smith, J.F. Teachings of the Prophet Joseph Smith. Salt Lake City, Utah: Deseret Book Company, 1974. 
Widtsoe, J.A. (Comp.) Discourses of Brigham Young. Salt Lake City, Utah: Deseret Book Company, 1954.

Requests for reprints to:

Craig R. Lundahl, Ph.D. Office of Research

Western New Mexico University

Silver City, New Mexico 88061 